\title{
12
}

\section{Examining Late Holocene marine reservoir effect in archaeological fauna at Hope Inlet, Beagle Gulf, north Australia}

\author{
Patricia Bourke \\ Quan Hua
}

\author{
'School of Australian Indigenous Knowledge Systems \\ Charles Darwin University \\ Darwin, NT 0909, Australia \\ ${ }^{2}$ Australian Nuclear Science and Technology Organisation \\ PMB1, Menai \\ NSW 2234, Australia
}

\section{Abstract}

This study examines the marine reservoir effect during the Late Holocene evolution of a small estuary in the Beagle Gulf $\left(12^{\circ} \mathrm{S}, 131^{\circ} \mathrm{E}\right)$. The paper aims at refining the local marine reservoir ages $(\mathrm{R})$ and correction values $(\Delta \mathrm{R})$, by ${ }^{14} \mathrm{C}$ analysis of stratigraphically associated archaeological fauna (marine shell, charcoal an $\mathrm{d}$ fish otoliths) from five proximate middens of different chronologies. The results suggest that a marine reservoir age of $340 \pm 70 \mathrm{yrs}$ is applicable to the Beagle Gulf for the Late Holocene, which is not significan tly different from that determined for nearby Van Dieman Gulf and the north Australian coast.

Keywords: Marine reservoir effect; Holocene; archaeological fauna; dating; middens; northern Australia.

Although there are known uncertainties identified in radiocarbon dating marine samples, particularly shell, related to system complexities (e.g. estuarine fluctuations, oceanic upwelling and organism physiology) of carbonate incorporation, shell offers important advantages to archaeologists, as Higham and Hogg (1995) have outlined:

1. it has the potential to date an event closely. Shellfish are mostly processed close to where they are collected

2. shell remains are ubiquitous in Australian coastal contexts

3. the marine calibration curve is smoother for marine than terrestrial samples, with fewer multiple intercepts and narrower derived calibrated ranges. 
By reducing the uncertainties and refining local marine reservoir correction factors for Australia's coasts, we may improve our confidence in the accuracy of ${ }^{14} \mathrm{C}$ based age determinations on this useful sample type. Researchers such as Reimer and Reimer (2001) and Ulm (2002) have indicated a need for localized estuary-specific data in order to accurately calibrate marine radiocarbon dates, given that local variations in marine reservoir corrections $(\Delta \mathrm{R})$ may be of the order of several hundred years.

This study examines the marine reservoir effect during the Late Holocene evolution of a small estuary - Hope Inlet, Shoal Bay in the Beagle Gulf $\left(12^{\circ} \mathrm{S}, 131^{\circ} \mathrm{E}\right)$. The project addresses questions on the a pplicability of the Marine Reservoir Age of $384 \pm 54$ yrs for north Australia (see Reimer and Reimer 2001). These questions have been raised by the close correspondence between some dates obtained on shell and charcoal from this region and for the neighbouring Van Dieman Gulf (Bourke 2000:162; Woodroffe and Mulrennan 1993:40-1; Woodroffe et al. 1988:98). This paper describes the results of investigations aimed at refining the local $\Delta \mathrm{R}$ value for the Beagle Gulf, by ${ }^{14} \mathrm{C}$ analysis of stratigraphically associated archaeological fauna (marine shell, charcoal and fish otoliths) from five proximate middens of different chronologies.

Projects such as this are becoming increasing important with further refinement of cultural chronologies in Australian archaeology (Ulm 2002:343 and see Ingram 1998; Spenneman and Head 1996). For example, radiocarbon dating of Anadara shell mounds on the Beagle Gulf coast suggest rapid formation (a few hundred years or less) and broad contemporaneity of some mounds in terms of human lifespans (Bourke 2004, 2005), that must be interpreted within the limits of error inherent in conventional radiocarbon dating (Head 1991; Ward 1994). Such issues have implications for palaeo-environmental models as well as models of past human coastal economies, often derived in large part from data from shell middens. These models require relatively precise dating if apparent correlations between environmental change and human adaptations and cultural contemporaneity between sites and regions are to be established with any confidence (e.g. Field 2004; Lourandos 1997; Nunn 2000; Veitch 1996; and see Spenneman and Head 1996). The deposits dated in this study comprise a representative sample of some two hundred shell and earth mounds on the Beagle Gulf coast. Many hundreds of these mounds accumulated around 2500 to 500 years $\mathrm{BP}$ right across the north Australian coast, from Princess Charlotte Bay to the Pilbara, (e.g. see Bailey 1999; Hiscock 1999; Figure 1) representing a period during the Late Holocene when Aboriginal people followed a tradition of mound building.

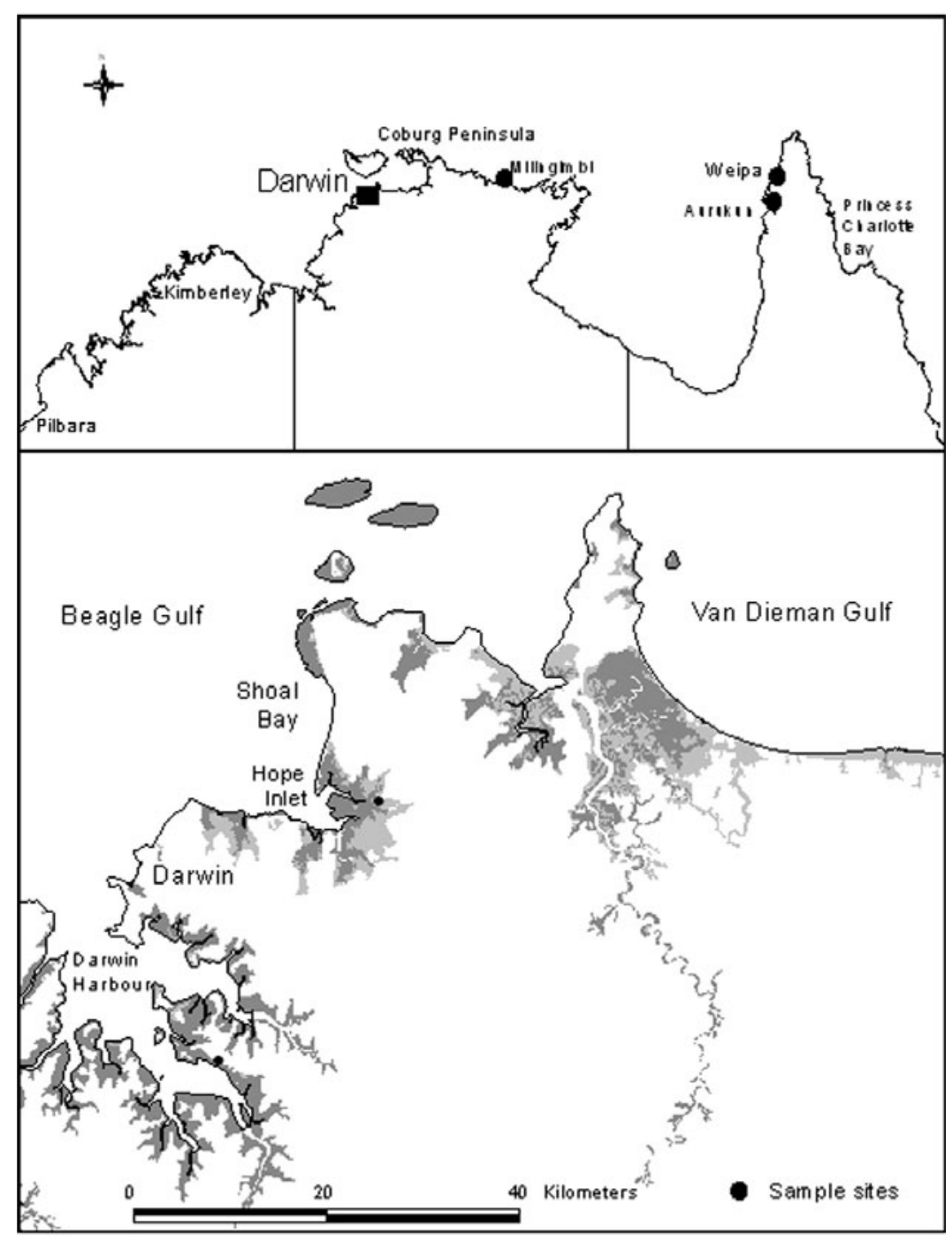

Figure 1. Location of sampled sites on the Beagle Gulf coast and some places mentioned in the text. 


\section{Site Description}

The data for this study comes from 25 radiocarbon ages on paired samples from five archaeological sites on the Beagle Gulf mainland (Table 1). Most of the dates are on a series of five shell/charcoal pairs and three shell/otolith/charcoal sets, taken from three Aboriginal midden sites at Hope Inlet (HI81, HI83, HI80), which are large stratified mounded shell deposits. These mounds are located within a few hundred metres of each other in adjacent ecological zones, on a hinterland headland and associated saltflats area partitioned by tidal channels, mangroves and swamps (Figure 2). Radiocarbon dates taken from these three deposits show that each accumulated relatively rapidly (within or much less than a few hundred years) and provide an opportunity to examine local marine reservoir factors over a relatively short time span between 2500 to 500 years BP of human occupation.

\begin{tabular}{|c|c|c|c|c|c|}
\hline Site & Lab Code & Sample & Av. Depth (cm) & $\delta^{13} \mathrm{C}(\%)$ & ${ }^{14} \mathrm{C}$ Age (yr BP) \\
\hline \multicolumn{6}{|c|}{ Hope Inlet } \\
\hline HI80 & *OZC956 & A. granosa & 3 & -3.0 & $960 \pm 80$ \\
\hline HI80 & *OZC957 & Charcoal & 3 & $-25 \#$ & $590 \pm 110$ \\
\hline HI80 & *OZC958 & A. granosa & 40 & -3.2 & $1190 \pm 90$ \\
\hline HI80 & *OZC959 & Charcoal & 40 & -24.5 & $860 \pm 80$ \\
\hline HI80 & *OZC960 & A. granosa & 48 & -3.5 & $1060 \pm 90$ \\
\hline HI80 & *OZC961 & Charcoal & 48 & -24.7 & $1020 \pm 90$ \\
\hline HI80 & *OZH889 & Otoliths & $48-52$ & -5.3 & $1165 \pm 35$ \\
\hline HI83 & Wk8252 & A. granosa & 16 & -3.2 & $2020 \pm 90$ \\
\hline HI83 & ${ }^{*} \mathrm{OZH} 893$ & Charcoal & $16-20$ & -25.6 & $1705 \pm 40$ \\
\hline HI83 & *OZI287 & Otolith & 19 & -3.9 & $1995 \pm 40$ \\
\hline HI83 & Wk6526 & A. granosa & 67 & -2.3 & $1910 \pm 70$ \\
\hline HI83 & Wk6527 & Charcoal & 67 & -25.3 & $1850 \pm 70$ \\
\hline HI81 & Wk6524 & A. granosa & 5 & -1.6 & $1900 \pm 70$ \\
\hline HI81 & ${ }^{*} \mathrm{OZH} 891$ & Charcoal & $5-9$ & -25.4 & $1570 \pm 35$ \\
\hline HI81 & *OZH892 & Otoliths & $5-9$ & -7.4 & $1820 \pm 40$ \\
\hline HI81 & *Wk16609 & A. granosa & 103 & -2.3 & $2005 \pm 33$ \\
\hline HI81 & ${ }^{*} \mathrm{Wk} 16610$ & Charcoal & 103 & -25.5 & $1635 \pm 38$ \\
\hline HI81 & Wk6523 & A. granosa & $140-42$ & -2.4 & $2220 \pm 70$ \\
\hline HI81 & ${ }^{*} \mathrm{OZH} 890$ & Charcoal & $140-42$ & -24.6 & $1835 \pm 35$ \\
\hline HI97 & *OZI286 & A. granosa & $14-16$ & -2.6 & $1800 \pm 40$ \\
\hline HI97 & *OZH896 & Charcoal & $14-16$ & -26.4 & $1345 \pm 45$ \\
\hline \multicolumn{6}{|c|}{ Darwin Harbour } \\
\hline MA7 & Beta-95257 & A. granosa & 5-15 & 0\# & $1870 \pm 70$ \\
\hline MA7 & Beta-95256 & Charcoal & $5-15$ & $-25 \#$ & $850 \pm 80$ \\
\hline MA7 & Beta-87872 & A. granosa & $30-40$ & $0 \#$ & $1220 \pm 60$ \\
\hline MA7 & Beta-87873 & Charcoal & $30-40$ & $-25 \#$ & $1070 \pm 80$ \\
\hline $\begin{array}{l}\text { Notes: } \\
{ }^{*} \text { AMS } \\
\text { \# Assu } \\
\text { The st } \\
\text { negati }\end{array}$ & $\begin{array}{l}\text { Cvalues } \\
\text { ope values for } \\
\text { ralues indicat }\end{array}$ & $\begin{array}{l}\text { nadara shell } \\
\text { aline enviro }\end{array}$ & $\begin{array}{l}\text { te that they can } \\
\text { (Head 1991). }\end{array}$ & n estua & ronment. More \\
\hline
\end{tabular}

Table 1. 14C ages obtained on shell, otolith and charcoal paired samples. 
Excavations revealed that under a compact surface layer of fragmented shell, soil and vegetation, these north Australian shell mounds are unconsolidated deposits, of large irregularly shaped objects (shells) packed loosely together, with interstitial spaces filled with a fine silty matrix. Nonetheless, these stratified middens exhibited a relatively high level of integrity, with little evident post-depositional disturbance, as seen in a stratigraphic profile of HI81 exposed after excavation (Figure 3). Defined layers were observed, of whole, densely packed shell alternating with ashy humic layers of more fragmented Anadara shell, other faunal remains and stone artefacts, which was borne out in the laboratory by analysis revealing a low level of shell breakage consistent with rapid deposition.

Site HI80 in particular, an elongated shell mound $(5.5 \mathrm{~m} \times 10 \mathrm{~m})$, located on the supra-tidal salt-flats of Hope Inlet, is a buried, saltencrusted, solidly compacted shell deposit which, due to the cohesive nature of the matrix, suggests a stratigraphic integrity not usually found in north Australian shell middens (Figure 4).

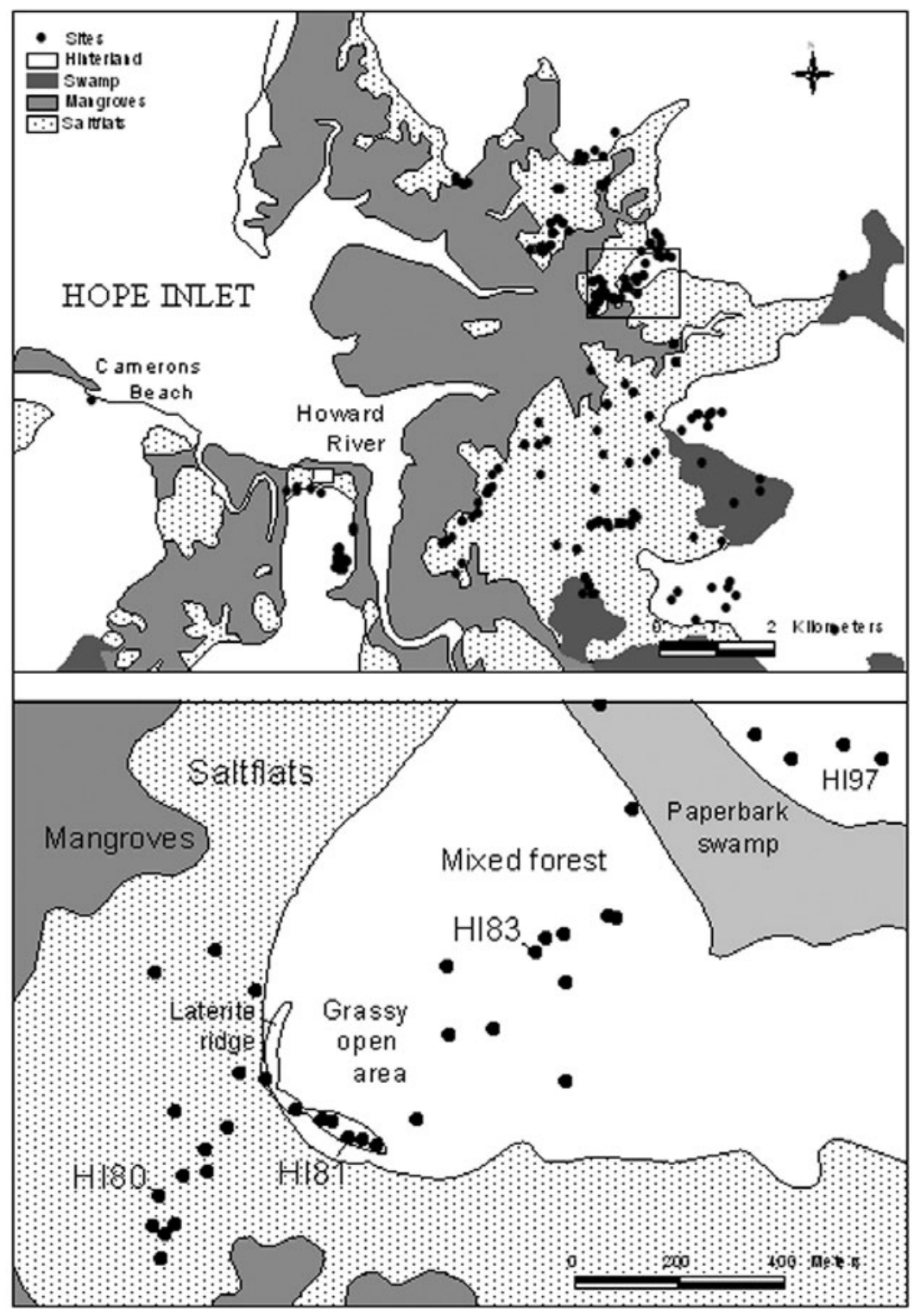

Figure 2. Locality plan of sites HI81, HI83, HI80 and HI97 at Hope Inlet.

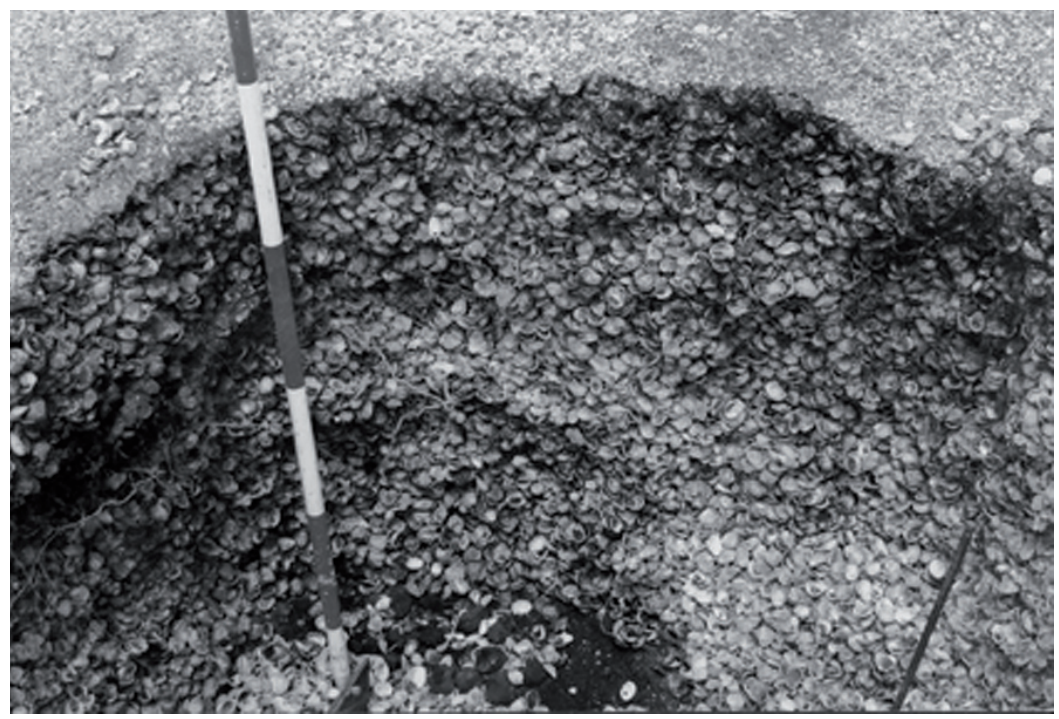

Figure 3. Stratigraphic profile of mound HI81, showing defined layers. 


\section{Materials and Methods}

The paired samples obtained from these deposits were mostly whole shells and charcoal chunks collected during excavations (by increments of average $3 \mathrm{~cm}$ spits), where they were observed to be in close stratigraphic proximity, often in situ inside shell valves (except the otoliths and the samples from HI97 which were selected in the lab).

The dates were obtained

with limited funds over a

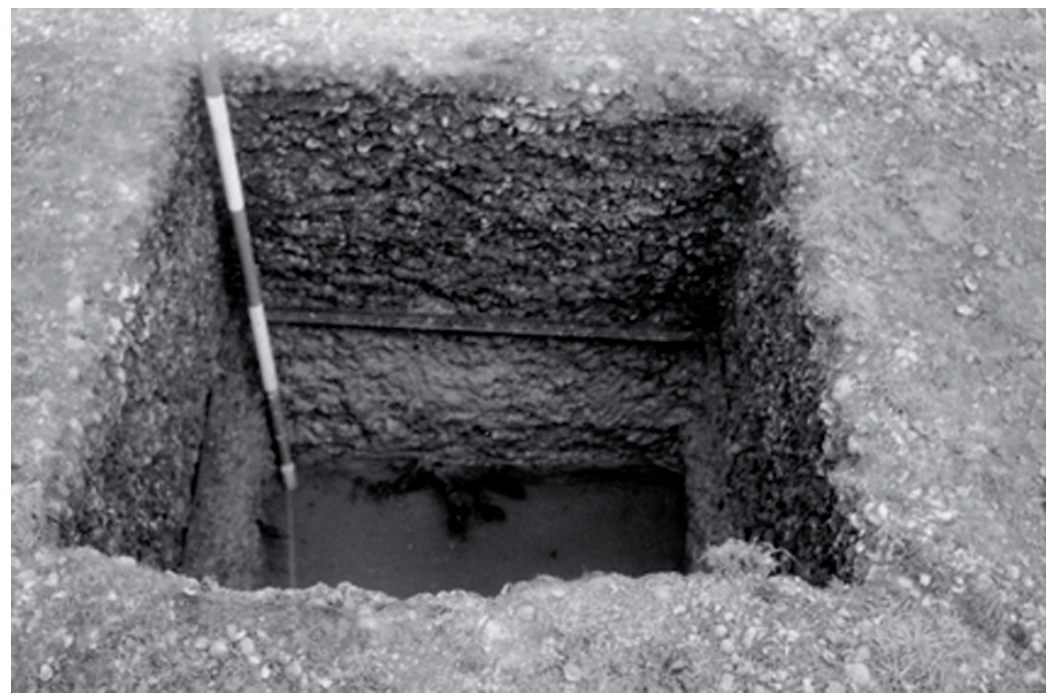

Figure 4. Stratigraphic profile of compacted shell deposit HI80. number of years (1996-2005).

Radiometric radiocarbon mea-

surements and AMS analysis were undertaken on the Hope Inlet sites by the Waikato Radio-carbon Dating Laboratory and the Australian Nuclear Science and Technology Organisation (ANSTO) AMS Facility. The estimate on the Darwin Harbour site was obtained in 1996 from Beta Analytic via The NWG Macintosh Centre for Quaternary Dating, the University of Sydney.

Initially, prior to the most recent 2005 grant from AINSE, the samples analysed were limited to four paired samples. Higham and Hogg (1995) argue that for a more robust analysis to refine the local $\Delta R$ value, it is necessary to minimise uncertainties associated with small sample size and sample type, by increasing the number of samples and range of faunal species used. We had hoped to obtain AMS analysis of other fauna, such as fish otoliths and terrestrial (macropod) bone/teeth samples also found in close stratigraphic association in the three shell mounds, to cross check against the dates on marine shell and on the charcoal, which was unidentified. Unfortunately the terrestrial samples were too fragmented and degraded, and not suitable for radiocarbon dating, so only the marine otolith samples were analysed. The possibility of a high inbuilt age in charcoal from an unknown species, identified as a problem in places with long-lived trees, such as New Zealand or the wet tropics of northeast Australia, (cf. Higham and Hogg 1995; Ulm 2002), is considered here to be less likely in the semi-arid tropics of this part of north Australia. This region is not known for old trees, due to the annual cycle of cyclones/storms, floods, fires and drought, in combination with the ravages of termites (e.g. Bowman and Panton 1994; Wilson and Bowman 1987).

The samples range from $0.1-1.5 \mathrm{~g}$ for the charcoal component and 12-40 $\mathrm{g}$ for the shell component. Anadara granosa, the dominant species that makes up the shell middens, was used in all cases, reducing possible variation due to difference in the relationship of specific species to the carbon cycle (Ulm 2002:331).

The samples were all within the average size of the Anadara granosa shells in these middens, which is between 25-35 mm in length. It takes about 15 months for Anadara cockles to reach a size of 18$32 \mathrm{~mm}$ and specimens larger than $53 \mathrm{~mm}$ are a rare occurrence (Broom 1985), so the samples are likely to represent relatively short life spans of around two years.

Anadara granosa is a marine bivalve cockle with limited mobility, which appears to be both a suspension and surface deposit-feeder, gaining nutrition from a mixture of microorganisms attached to detritus and benthic microalgae that are easily re-suspended from the substrate (Broom 1985). Studies suggest that the use for examining local reservoir conditions, of species that ingest detritus can be problematic, as ingested organic carbon from a mixture of sources (including terrestrial organic carbon 
introduced into estuaries by rivers), can be metabolised and incorporated into shell (Hogg et al. 1998, Tanaka et al. 1986; cited in Ulm 2002:330).

In this current analysis an additional marine sample type was employed to minimise uncertainties associated with the single species sample of Anadara granosa shell. We have used samples of the otoliths of forktailed catfish (Arius sp.), to allow a cross check against possible systematic effects of carbon incorporation in the Anadara species and thus check the validity of ages obtained on this shell (Spenneman and Head 1996). Helen Larson of the Museum and Art Galleries of the Northern Territory (MAGNT) estimated that forktailed catfish species, which live in the shallow, inshore waters of the estuarine system, have a lifespan of some 10-15 years.

Most of radiocarbon dates in this study were analysed at the ANSTO AMS facility (Table 1). The chemistry procedures for AMS ${ }^{14} \mathrm{C}$ sample preparation at this facility were as follows:

For charcoal samples, the samples were washed with $2 \mathrm{M} \mathrm{HCl}$ at $60^{\circ} \mathrm{C}$ for two hours to remove any possible carbonate contamination. The samples were then treated with $1-2 \% \mathrm{NaOH}$ at $60^{\circ} \mathrm{C}$ until all humic acid contamination was removed, followed by another $2 \mathrm{M} \mathrm{HCl}$ treatment at room temperature for two hours. Before combustion, the pre-treated samples were oven-dried at $60^{\circ} \mathrm{C}$ for two days.

For shell and otolith samples, the samples were washed several times with deionised water in an ultrasonic bath, then were leached for 10-15 minutes in dilute $\mathrm{HCl}$ to remove any surface contamination and possible secondary carbonate. They were then dried in an oven at $60^{\circ} \mathrm{C}$ for two days.

The cleaned samples were combusted (for charcoal) or hydrolysed (for shell and otolith) to $\mathrm{CO}_{2}$, then converted to graphite using the $\mathrm{Fe} / \mathrm{H}_{2}$ method (Hua et al. 2001). AMS ${ }^{14} \mathrm{C}$ measurements were performed using the ANTARES facility at ANSTO (Fink et al. 2004).

\section{Results and Discussion}

\section{Radiocarbon results}

Our ${ }^{14} \mathrm{C}$ results for shell, otolith and charcoal samples from the study sites, expressed in conventional radiocarbon ages, after correction for isotopic fractionation using $\delta^{13} \mathrm{C}$ values, are presented in Table 1. There is a good agreement between ${ }^{14} \mathrm{C}$ ages of shells and those of otoliths as they overlap each other within $1 \sigma$ uncertainty. This gives us confidence in our ${ }^{14} \mathrm{C}$ ages of marine samples. If there were a proble $\mathrm{m}$ then the otoliths would systematically date older than the shell, but there was no difference seen with just the three samples dated.

To calibrate ${ }^{14} \mathrm{C}$ ages of charcoal samples, we used the IntCal04 calibration data set (Reimer et al. 2004) and the CALIB program version 5.01 (http://radiocarbon.pa.qub. ac.uk/). It is well known that the atmospheric ${ }^{14} \mathrm{C}$ levels for different parts of the world are not the same (e.g., Stuiver and Braziunas 1998; Hua et al. 2004a). Therefore, a regional atmospheric ${ }^{14} \mathrm{C}$ offset correction has been applied for our study sites in the tropics during the age calibration process, using IntCal04 data set, which represents atmospheric ${ }^{14} \mathrm{C}$ levels for northern temperate regions. We adopted an atmospheric $\Delta^{14} \mathrm{C}$ offset between our sites at $\sim 12^{\circ} \mathrm{S}$ and the northern temperate regions at $40-50^{\circ} \mathrm{N}$ of $\sim 2 \%$ (atmospheric ${ }^{14} \mathrm{C}$ level at our sites is lower) from the modelling work of Braziunas et al. (1995). This value is equivalent to $\sim 16{ }^{14} \mathrm{C}$ years (terrestrial samples growing at our sites are older) and to simplify the issues we assumed that this value is constant through time. Sixteen years was subtracted from all conventional radiocarbon ages of charcoal samples before these were converted to calendar ages using the CALIB program and IntCal04 data set. Calibrated ages $(1 \sigma)$ of charcoal samples are reported in column 7 of Table 2. 


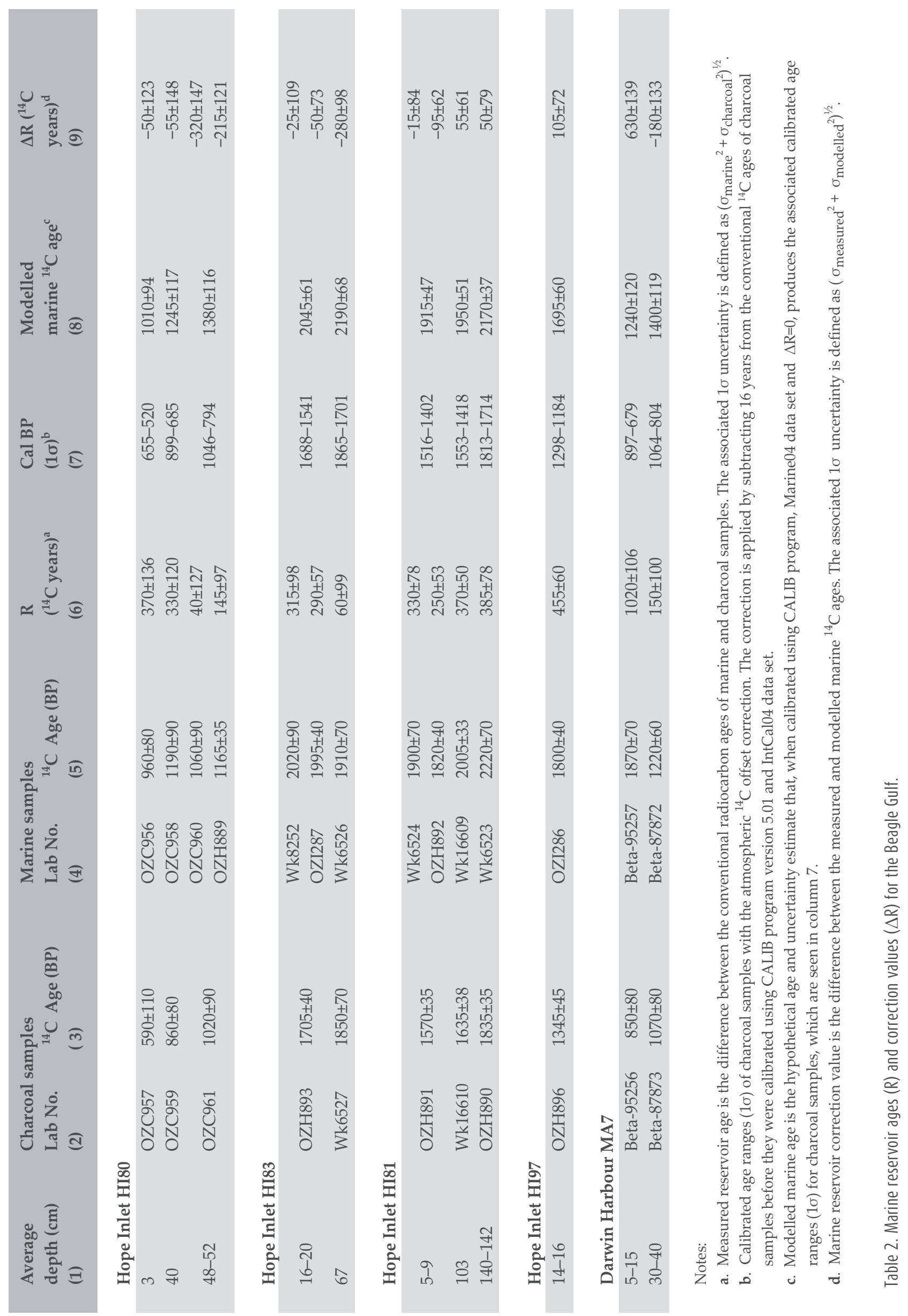


At Hope Inlet, two shell/charcoal paired samples and one shell/charcoal/otolith sample dated from mound HI81 show that this mound formed on a laterite ridge at the uplands edge of mudflats over a few centuries between ca 1800 and 1400 cal BP (Bourke 2004). The date the mound began to form follows a major phase of mudflat build-out dated ca 2300 cal BP at Shoal Bay (Woodroffe and Grime 1999). Dating of one shell/charcoal pair and one shell/charcoal/otolith sample shows rapid formation of mound HI83, located some $300 \mathrm{~m}$ inland of HI81, also within this period. One shell/charcoal pair taken from a $30 \mathrm{~cm}$ wide midden layer within an earth mound (site HI97) that lies inland of the three sampled shell mounds, suggests that this mound formed soon after this period. Dating of two shell/charcoal pairs and one shell/charcoal/otolith sample shows that mound HI80 was formed on nearby saltflats between ca 900 and 500 cal BP, many centuries after HI83 and HI81 ceased accumulating, and following another phase of mudflat build-out and chenier building around 1000-900 cal BP at Shoal Bay (Woodroffe and Grime 1999).

In the neighbouring Darwin Harbour estuary system, dating of two shell/charcoal pairs from a smaller shell midden site (MA7), suggests that this mound formed around the same period as HI80, around 900-700 cal BP.

\section{Marine reservoir ages and correction values}

A marine reservoir age $(R)$ for a particular region at a time $t$ is determined as:

Measured $R(t)=$ Measured marine ${ }^{14} \mathrm{C}$ age $(t)-$ Measured charcoal ${ }^{14} \mathrm{C}$ age $(t)$

Measured marine and charcoal ${ }^{14} \mathrm{C}$ ages are presented in columns 5 and 3 of Table 2, respectively. Our $\mathrm{R}$ values are reported in column 6 of Table 2.

According to Stuiver and Braziunas (1993), a marine reservoir correction value $(\Delta \mathrm{R})$ for a particular region at a time $t$ is defined as:

$$
\begin{aligned}
& \Delta \mathrm{R}=\text { measured } \mathrm{R}(\mathrm{t})-\text { modelled } \mathrm{R}(\mathrm{t})+\Delta \mathrm{Ra} \\
& \text { or } \\
& \Delta \mathrm{R}=\text { measured marine }{ }^{14} \mathrm{C} \text { age }(\mathrm{t})-\text { modelled marine }{ }^{14} \mathrm{C} \text { age }(\mathrm{t})+\Delta \mathrm{Ra}
\end{aligned}
$$

where $\Delta \mathrm{Ra}$ is a fraction of $\Delta \mathrm{R}$ due to a regional atmospheric ${ }^{14} \mathrm{C}$ offset.

For this study, $\Delta \mathrm{Ra}$ is different from zero and was incorporated into the calculation of our $\Delta \mathrm{R}$ values during the process of estimating modelled marine ${ }^{14} \mathrm{C}$ age $(\mathrm{t})$ following the method described in Owen (2002).

The procedure of $\Delta \mathrm{R}$ determination is as follows:

- A 16-yr offset correction was applied for all radiocarbon ages of charcoal samples before they were calibrated using CALIB program and IntCal04 data set. Calibrated results are presented in column 7 of Table 2 .

- The modelled marine age and uncertainty estimate (reported in column 8 of Table 2) are determined by successive approximation as the values that, when calibrated with Marine04 curve (Hughen et al. 2004) and $\Delta R=0$, result in the calibrated ages of charcoal samples reported in column 7 of Table 2. The smooth shape of Marine04 curve ensures that there is almost always a unique solution (Owen 2002).

- $\Delta \mathrm{R}$ value is the difference between measured and modelled marine ${ }^{14} \mathrm{C}$ ages, which are presented in columns 5 and 8 of Table 2, respectively. $\Delta R$ values of this study are reported in column 9 of Table 2. 
$\mathrm{R}$ and $\Delta \mathrm{R}$ values for Hope Inlet, Beagle Gulf estimated from our ${ }^{14} \mathrm{C}$ data are also illustrated in Figures 5 and 6 . $R$ values range from 40 to 1020 years. Most values are from 250 to $455 \mathrm{yrs}$, and only one data point shows a very high value of $1020 \mathrm{yrs}$ for MA7 at $5-15 \mathrm{~cm}$, and four data points show low values ranging from 40 to $150 \mathrm{yrs}$, for HI80 at $48-52 \mathrm{~cm}$, HI83 at $67 \mathrm{~cm}$ and MA7 at $30-40 \mathrm{~cm}$. Similarly, $\Delta \mathrm{R}$ values vary from -320 to 630 yrs. Most data are in the range of -95 to 105 yrs with the exception of four low values from -320 to $-180 \mathrm{yrs}$, and one high value of $630 \mathrm{yrs}$. Note that the four pairs showing low $R$ values also show low $\Delta R$ values. Similarly, the pair showing high $R$ value also shows high $\Delta R$ value.

For MA7, a pair sample at $5-15 \mathrm{~cm}$ shows a very high $\mathrm{R}$ value of $1020 \mathrm{yrs}$ and the other pair at $30-40 \mathrm{~cm}$ shows a low $\mathrm{R}$ value of $150 \mathrm{yrs}$. It seems that there may be a stratigraphic problem for this midden, possibly due to upward vertical movement of shell through post-depositional disturbance by goanna activity that is evident in this mound. The data derived from this mound may therefore not be reliable, at least for MA7 at $5-15 \mathrm{~cm}$.

For HI80, two pair samples at $48-52 \mathrm{~cm}$ show low $\mathrm{R}$ values of $40 \mathrm{yrs}$ for the charcoal/Anadara granosa pair, and 145 yrs for the charcoal/ otolith pair. Contami-nation of shell or otolith samples by secondary carbonate as a result of their contact to groundwater or seawater may cause low $R$ values. However, the fish otolith (OZH889) had a smooth surface indicating no or minimal contamination by secondary carbonate. Both marine samples (OZC960 and OZH889) were treated at ANSTO with dilute acids to remove any surface contamination before dating and had similar ${ }^{14} \mathrm{C}$ ages. This implies contamination by secondary carbonate is not the cause for these low $R$ values.

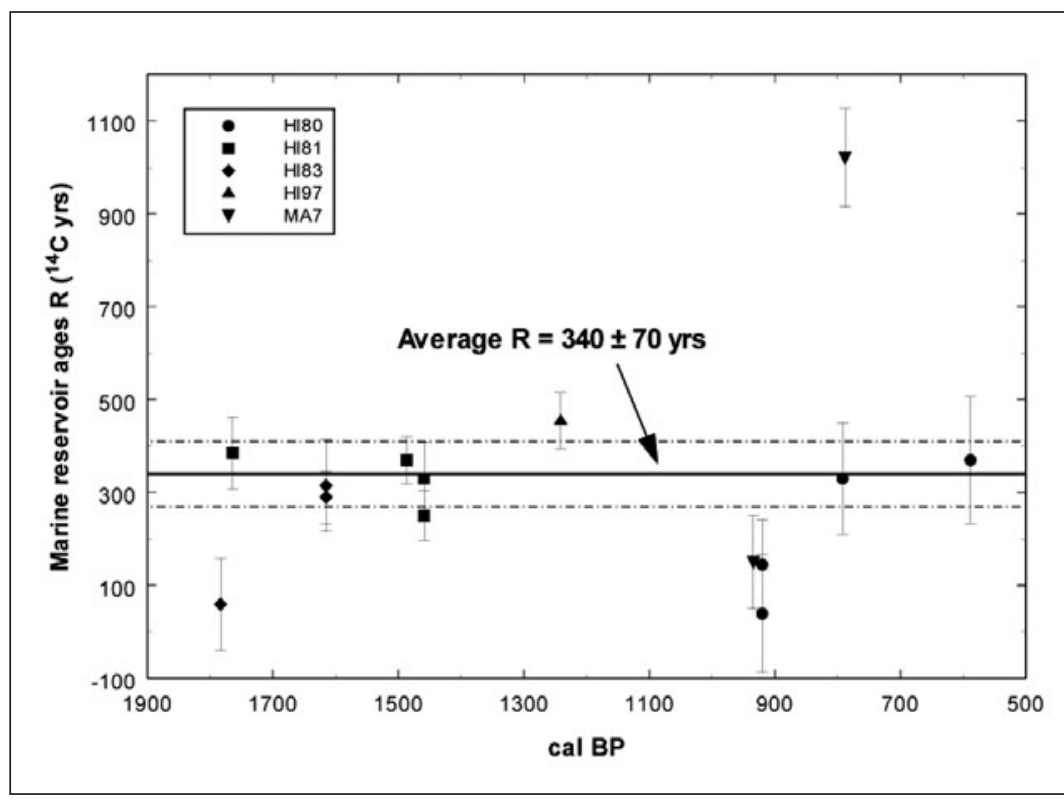

Figure 5. Marine reservoir and average $R$ for the Beagle Gulf coast determined from this study. All symbols are plotted in the middle of calibrated age ranges reported in column 7 of Table 2. Very low (from 40 to 150 years) and high (1020 years) values of R were not included in the estimate of the average value.

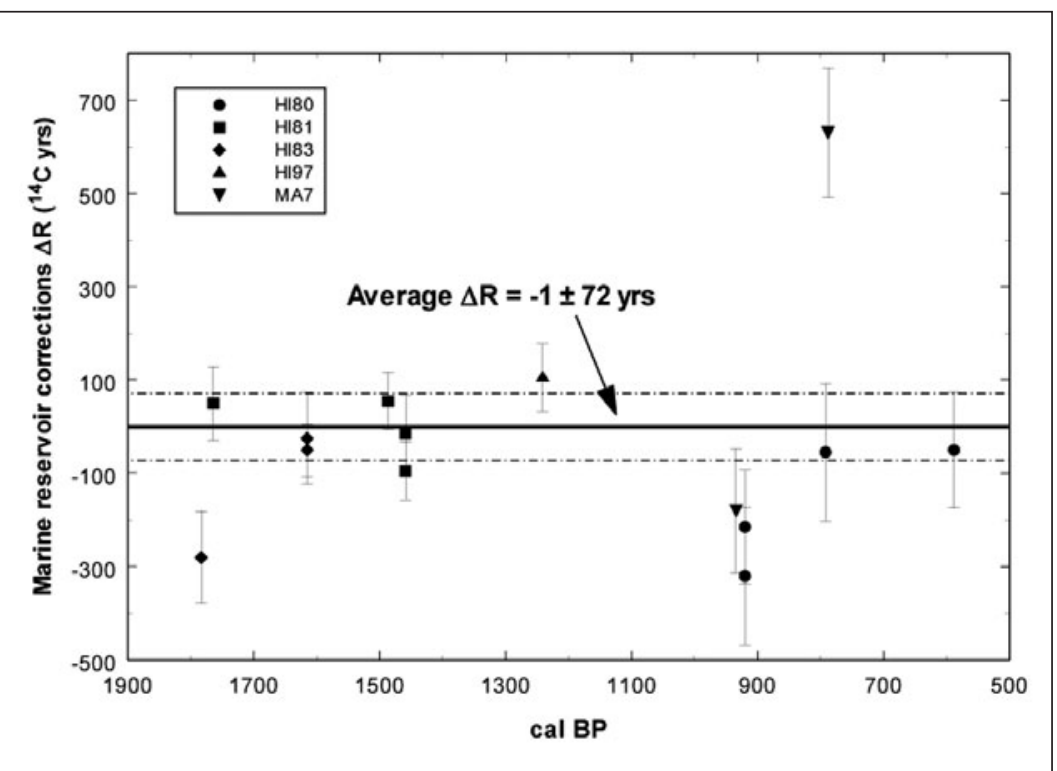

Figure 6. $\Delta R$ marine corrections for the Beagle Gulf coast determined from this study. All symbols are plotted in the middle of calibrated age ranges reported in column 7 of Table 2. Very low (from -320 to -180 years) and high (630 years) values of $\Delta R$ were not included in the estimate of the average value. 
The low $\mathrm{R}$ and $\Delta \mathrm{R}$ values at the base of the HI80 deposit occurs for both the shell and otolith samples. These are taken from the base of a defined layer between $48-52 \mathrm{~cm}$ depth, containing a high proportion of the bivalves Marcia hiantina and Anadara inaequivalvis in the otherwise Anadara dominated deposit (Bourke 2004). These two species thrive in coarser, sandier substrates than the finer, silty muddy substrates preferred by the dominant Anadara granosa. In site MA7 too, Marcia hiantina makes up 20\% more of the total shell taxa than in a nearby mound (MA1) dated to an earlier period (Bourke 2005: Tables 1 and 2). The results suggest that something occurred around 1000-900 cal BP causing low $R$ and $\Delta R$ valu es, as this can be seen from three data points from two different sites (HI80 and MA7). Sites HI80 at Hope Inlet and MA7 on the Darwin Harbour shoreline are approximately $25 \mathrm{~km}$ apart in neighbouring estuaries.

Thus these results may reflect short-term environmental change on a regional rather than local micro-scale confined to the Hope Inlet area, and imply high rainfall or storms and changes in relative quantities of sand, mud, river and sea currents and the location of sand banks, as observed on the Arnhem Land coast during the 1970s (Meehan 1982:62,70, 78, 142).

For HI83, a pair sample at $67 \mathrm{~cm}$ shows a low R value of $66 \mathrm{yrs}$. A mismatch between shell and charcoal may cause a low $\mathrm{R}$ value, but one author (PB) believes that this is not the case here, as the shell/ charcoal pair for site HI83 at $67 \mathrm{~cm}$ was recovered in secure stratigraphic association, consisting of a large chunk (5 g) of charcoal cemented together with an Anadara granosa valve in a clay base. Contamination of shell by secondary carbonate may also cause a low $\mathrm{R}$ value. This contamination can be detected by $\mathrm{X}$-ray diffraction (XRD) analysis. This shell sample (Wk6526) measured at Waikato was analysed by XRD to make sure it had not suffered any secondary carbonate contamination. This indicates secondary carbonate contamination may not be the cause for this low R value. Also, a low R value for HI83 at $67 \mathrm{~cm}$ is thought not to be due to environmental changes at $1800 \mathrm{cal} \mathrm{BP}$, because a pair sample at HI81 site at $140-142 \mathrm{~cm}$ shows a reasonable R of $385 \pm 75 \mathrm{yrs}$ at that time. A possible cause for a low R value for HI83 at $67 \mathrm{~cm}$ is the old wood problem. However, this possibility is unlikely as the semi-arid tropics of north Australia are not known for old trees (see discussions in Materials and Methods) (cf. Higham and Hogg 1995). It is also possible that the charcoal sample is a reworked charcoal that has survived in the surrounding environment for a long period of time before finally ending up in the midden. The low $\mathrm{R}$ value for HI83 at $67 \mathrm{~cm}$ is not well understood and should be investigated in the future.

If these very high and low values of $R$ are not taken into account, an error-weighted average $R$ for Hope Inlet of $340 \pm 70{ }^{14} \mathrm{C}$ yrs for the period $1800-600 \mathrm{cal}$ BP can be inferred (Figure 5). Similarly, if these high and low $\Delta R$ values are not included, an error-weighted average $\Delta R$ for Hope Inlet of $-1 \pm 72$ ${ }^{14} \mathrm{C}$ yrs for the period $1800-600 \mathrm{cal} \mathrm{BP}$ can be estimated (Figure 6). The uncertainties associated with error weighted average values of $R$ and $\Delta R$ are their standard deviations.

\section{Conclusions}

The results of this study, based on a small number of dates obtained on paired samples - shell/charcoal pairs and shell/otolith/charcoal sets from five archaeological deposits - indicate for the Hope Inlet estuary on the Beagle Gulf mainland, values of an average marine reservoir age (R) of $340 \pm 70 \mathrm{yrs}$ and $\Delta \mathrm{R}$ marine correction of $-1 \pm 72 \mathrm{yrs}$ for the period $1800-600 \mathrm{cal} \mathrm{BP}$. This marine reservoir age for the Beagle Gulf for the Late Holocene is not significantly different from the $R$ value of $384 \pm 58 \mathrm{yrs}$ deter mined for the north Australian coast (see Reimer and Reimer 2001) as the two values overlap each other within $1 \sigma$ uncertainty. Similarly, the weighted mean $\Delta \mathrm{R}$ value for Hope Inlet is not significantly different from the regional mean $\Delta \mathrm{R}$ value of $64 \pm 24 \mathrm{yrs}$ quoted in Hua et al. (2004b) for NW Australia and Java, as the two values overlap each other within $1 \sigma$ uncertainty.

The results also show lower values of $\mathrm{R}$ and $\Delta \mathrm{R}$ ranging from 40 to $150 \mathrm{yrs}$ and from -180 to -320 yrs, respectively, for a short period during 1000-900 cal BP. These low values, based on only 3 paired samples from two different shell middens, may reflect short-term environmental change (e.g. high rainfall or storms) on a regional scale. More data are needed to confirm this observation. 
Studies such as this that provide localized estuary-specific data contribute to coastal and estuarine data sets required as a baseline for accurate calibration of marine radiocarbon dates, which are increasingly important in refining archaeological and environmental chronologies. Further studies that may be useful to investigate local variations in marine ${ }^{14} \mathrm{C}$ reservoir ages would be to locate and measure the reservoir ages of historic shells for this region, as well as stable oxygen and carbon isotopic measurements of the historic and archaeological shells.

\section{Acknowledgements}

We gratefully acknowledge funding from AINSE for AMS ${ }^{14} \mathrm{C}$ measurements (grants 97/185R and 05/014). We also thank Paula Reimer and Fiona Petchey for their critical comments which improved the manuscript. 


\section{References}

Bailey, G. N. 1999. Shell mounds and coastal archaeology in northern Queensland. In J. Hall and I. McNiven (eds), Australian coastal archaeology, pp 105-112. Canberra: ANH Publications, Department of Archaeology and Natural History, Research School of Pacific and Asian Studies, The Australian National University.

Bourke, P. M. 2000. Late Holocene Indigenous economies of the tropical Australian coast: An archaeological study of the Darwin Region. Unpublished Ph.D. thesis. Darwin: Northern Territory University.

Bourke, P. 2004. Three Aboriginal shell mounds at Hope Inlet: Evidence for coastal, not maritime Late Holocene economies on the Beagle Gulf mainland, northern Australia. Australian Archaeology 59:10-22.

Bourke, P. 2005. Archaeology of shell mounds of the Darwin coast: Totems of an ancestral landscape. In P. Bourke, S. Brockwell and C. Fredericksen (eds), Darwin archaeology: Aboriginal, Asian and European heritage of Australia's Top End, pp 29-48. Darwin: Charles Darwin University Press.

Bowman, D. M. J. S. and W. J. Panton. 1994. Fire and cyclone damage to woody vegetation on the north coast of the Northern Territory, Australia. Australian Geographer 25:32-35.

Braziunas, T. F., I. Y. Fung and M. Stuiver. 1995. The preindustrial atmospheric ${ }^{14} \mathrm{CO} 2$ latitudinal gradient as related to exchanges among atmospheric, oceanic, and terrestrial reservoirs. Global Biogeochemical Cycles 9:565-584.

Broom, M. J. 1985. The biology and culture of marine bivalve mollusca of the genus Anadara. Manila: Philippines: International Centre for Living Aquatic Resources Management.

Field, J. 2004. Environmental and climatic considerations: A hypothesis for conflict and the emergence of social complexity in Fijian prehistory. Journal of Anthropological Archaeology 23:79-99.

Fink, D., M. Hotchkis, Q. Hua, G. Jacobsen, A. M. Smith, U. Zoppi, D. Child, C. Mifsud, H. van der Gaast, A. Williams and M. Williams. 2004. The ANTARES AMS Facility at ANSTO. Nuclear Instruments and Methods in Physics Research B 223-224:109-15.

Head, J. 1991. The radiocarbon dating of freshwater and marine shells. In R. Gillespie (ed.), Quaternary dating workshop 1990, pp 16-18. Canberra: Department of Biogeography and Geomorphology, The Australian National University.

Higham, T. F. G. and A. G. Hogg 1995. Radiocarbon dating of prehistoric shell from New Zealand and calculation of the $\Delta \mathrm{R}$ value using fish otoliths. Radiocarbon 37(2):409-416.

Hiscock, P. 1999. Holocene coastal occupation of western Arnhem Land. In J. Hall and I. McNiven (eds), Australian coastal archaeology, pp 91-103. Canberra: ANH Publications, Department of Archaeology and Natural History, Research School of Pacific and Asian Studies, The Australian National University.

Hogg, A. G., T. F. G. Higham and J. Dahm. 1998. ${ }^{14} \mathrm{C}$ dating of modern marine and estuarine shellfish. Radiocarbon 40:975-984.

Hua, Q., G. E. Jacobsen, U. Zoppi, E. M. Lawson, A. A. Williams, A. M. Smith and M. J. McGann 2001. Progress in radiocarbon target preparation at the ANTARES AMS Centre. Radiocarbon 43:275-82.

Hua, Q., M. Barbetti, U. Zoppi, D. Fink, M. Watanasak and G. E. Jacobsen. 2004a. Radiocarbon in tropical tree rings during the Little Ice Age. Nuclear Instruments and Methods in Physics Research B 223-224:489-494.

Hua, Q., C. D. Woodroffe, M. Barbetti, S. G. Smithers, U. Zoppi and D. Fink. 2004b. Marine reservoir corrections for the Cocos (Keeling) Islands, Indian Ocean. Radiocarbon 46:603-610.

Hughen, K. A., M. G. L. Baillie, E. Bard, J. W. Beck, C. J. H. Bertrand, P. G. Blackwell, C. E. Buck, G. S. Burr, K. B. Cutler, P. E. Damon, R. L. Edwards, R. G. Fairbanks, M. Friedrich, T. P. Guilderson, B. Kromer, G. McCormac, S. Manning, C. Bronk Ramsey, P. J. Reimer, R. W. Reimer, S. Remmele, J. R. Southon, M. Stuiver, S. Talamo, F. W. Taylor, J. van der Plicht and C. E. Weyhenmeyer. 2004. Marine04 marine radiocarbon age calibration, 0-26 cal kyr BP. Radiocarbon 46:1059-1086. 
Ingram, B. L. 1998. Differences in radiocarbon age between shell and charcoal from a Holocene shell-mound in northern California. Quaternary Research 49:102-110.

Lourandos, H. 1997. Continent of hunter-gatherers: New perspectives in Australian prehistory. Cambridge: Cambridge University Press.

Meehan, B. 1982. Shell bed to shell midden. Canberra: Australian Institute of Aboriginal Studies.

Nunn, P. 2000. Environmental catastrophe in the Pacific Islands around AD 1300. Geoarchaeology: An International Journal 15(7):715-740.

Owen, B. D. 2002. Marine carbon reservoir age estimates for the far south coast of Peru. Radiocarbon 44:701-708.

Reimer, P. and R. Reimer 2001. A marine reservoir correction database and on-line interface. Radiocarbon 43:461-463. URL:http://calib.org/marine.

Reimer, P. J., M. G. L. Baillie, E. Bard, A. Bayliss, J. W. Beck, C. J. H. Bertrand, P. G. Blackwell, C. E. Buck, G. S. Burr, K. B. Cutler, P. E. Damon, R. L. Edwards, R. G. Fairbanks, M. Friedrich, T. P.

Guilderson, A. G. Hogg, K. A. Hughen, B. Kromer, G. McCormac, S. Manning, C. Bronk Ramsey, R. W. Reimer, S. Remmele, J. R. Southon, M. Stuiver, S. Talamo, F. W. Taylor, J. van der Plicht and C. E. Weyhenmeyer. 2004. IntCal04 terrestrial radiocarbon age calibration, 0-26 cal kyr BP. Radiocarbon 46:1029-1058.

Spennemann, D. H. R. and M. J. Head. 1996. Reservoir modification of radiocarbon signatures in coastal and near-shore waters of eastern Australia: The state of play. Quaternary Australasia 14/1:32-39.

Stuiver, M. and Braziunas, T. F. 1993. Modeling atmospheric ${ }^{14} \mathrm{C}$ influences and ${ }^{14} \mathrm{C}$ ages of marine samples to 10,000 BC. Radiocarbon 35:137-189.

Stuiver, M. and Braziunas, T. F. 1998. Anthropogenic and solar components of hemispheric ${ }^{14} \mathrm{C}$. Geophysical Research Letters 25:329-332.

Tanaka, N., M. C. Monaghan and D. M. Rye. 1986. Contribution of metabolic carbon to mollusc and barnacle shell carbonate. Nature 320: 520-523.

Ulm, S. 2002. Marine and estuarine reservoir effects in Central Queensland, Australia: Determination of R values. Geoarchaeology: An International Journal 17(4):319-348.

Veitch, B. 1996. Evidence for mid-Holocene change in the Mitchell Plateau, Northwest Kimberley, Western Australia," in P. Veth and P. Hiscock (eds), Archaeology of Northern Australia. Tempus 4, pp 66-89. St. Lucia, Queensland: Anthropology Museum, University of Queensland.

Ward, G. K. 1994. On the use of radiometric determinations to 'date' archaeological events. Australian Aboriginal Studies 2:106-109.

Wilson, B. A. and D. M. J. S. Bowman 1987. Fire, storm, flood and drought: The vegetation ecology of Howards Peninsula, Northern Territory, Australia. Australian Journal of Ecology 12:165-74.

Woodroffe, C. D. and D. Grime. 1999. Storm impact and evolution of a mangrove-fringed chenier plain, Shoal Bay, Darwin, Australia. Marine Geology 159:303-321.

Woodroffe, C. D. and M. E. Mulrennan 1993. Geomorphology of the lower Mary River plains, Northern Territory. Darwin: North Australia Research Unit, Australian National University.

Woodroffe, C. D., J. M. A. Chappell and B. G. Thom 1988. Shell middens in the context of estuarine development, South Alligator River, Northern Territory. Archaeology in Oceania 23:95-103. 